\title{
OPERATIONAL EFFICIENCY AND ENVIRONMENTAL IMPACT OF WASTEWATER TREATMENT PLANTS IN LITHUANIAN RURAL AREAS
}

\begin{abstract}
Midona DAPKIENĖ, Department of Water Engineering, Vytautas Magnus University, K. Donelaičio g. 58, 44248 Kaunas, Lithuania, midona.dapkiene@vdu.lt (corresponding author)

Laima ČESONIENĖ, Department of Water Engineering, Vytautas Magnus University, K. Donelaičio g. 58, 44248 Kaunas, Lithuania, laima.cesoniene1@vdu.lt

Jolanta KUZMICKIENĖ, Department of Water Engineering, Vytautas Magnus University, K. Donelaičio g. 58, 44248 Kaunas, Lithuania, jolanta.kuzmickiene@googlemail.com

The aim of the paper was to determine the operational efficiency and environmental impact of five small wastewater treatment plants (WWTPs) in Ukmerge district. The efficiency of these WWTPs, reconstructed by applying the same vertical flow labyrinth technology was calculated according to the most important pollution indicators: biochemical oxygen consumption in 7 days $\left(\mathrm{BOD}_{7}\right)$, total phosphorus (TP) and total nitrogen (TN) in period 2017-2020. It was found that the lowest operational efficiency of Taujenai wastewater treatment plant was according to $\mathrm{BOD}_{7}(94-96 \%)$. The lowest treatment efficiency of total nitrogen was determined in Dainava WWTP (88-95\%). The highest treatment efficiency according to total phosphorus was in Šventupe WWTP (86-92\%), the lowest in Žemaitkiemis WWTP (72-85\%). In order to evaluate the impact of wastewater treatment plants on the environment, their Life Cycle Assessment (LCA) was performed. Sludge from wastewater treatment process has been found to have the highest environmental impact and fuel consumption for transport the lowest. Of the five wastewater treatment plants examined, the Vidiškiai wastewater treatment plant has the largest impact on the environment, and Šventupe WWTP has the lowest.
\end{abstract}

Keywords: wastewater treatment plant, efficiency, Life Cycle Assessment

\section{INTRODUCTION}

In order to protect surface water bodies from pollution, efforts are being made to treat wastewater discharged into them as efficiently as possible. However, the more efficiently the wastewater is treated, the higher the amount of sludge is being generated, more electricity is being used to operate the equipment, and more chemicals are often being used to remove the nutrients (Sperling, 2007). Therefore, it is important not only to assess the efficiency of wastewater treatment plants, but also their impact on the environment. There are many options for wastewater treatment and sludge treatment. Designing for sustainability is very important during the planning phase and pre-selection of wastewater treatment plants, especially in rural areas (Machado et al., 2007).

Life Cycle Assessment (LCA) allows to compare the environmental impact of processes and systems and assess their sustainability throughout their life cycle, from raw material extraction, transportation, recycling to waste collection and sustainability of a wastewater treatment systems (Tillman and Baumann, 2004; Buyukkamaci, 2013; Silvenius et al., 2019). LCA is a methodological structure that allows to calculate and evaluate various categories of environmental impact: global warming potential, ozone layer depletion, eutrophication, acidification, photooxidant formation, ecotoxicity, human toxicity, biotic and abiotic resources, which typically occur during a particular process cycle (Environmental Assessment..., 2000; Rebitzer et al., 2003; Navickas and Venslauskas, 2012; Zhang et al., 2013; Silvenius et al., 2019). The main impact category is global warming potential (GWP), which expresses climate change by the emission of greenhouse gases like carbon dioxide $\left(\mathrm{CO}_{2}\right)$ and methane $\left(\mathrm{CH}_{4}\right)$ and it is measured in $\mathrm{CO}_{2}$ equivalents (Goedkoop et al., 2010; Acero et al., 2017; Zimele et al., 2019).

LCA can be used to evaluate and compare wastewater treatment plants with different treatment technologies. Although most research is focused on energy consumption, research is also being carried out to assess the greenhouse effect, its emissions, toxicity and eutrophication (Munoz et al., 2010).

The activated sludge wastewater treatment process can effectively remove organic pollutants but consumes a lot of electricity. Anaerobic treatment is a more environmentally friendly treatment technology than aerobic treatment due to low electricity demand and useful biogas production. Nature-based systems are offered as alternatives with lower environmental impact for LCA compared to conventional technologies (Brix et al., 1999).

Copyright (C) 2021 The Authors. Published by Vytautas Magnus University. This is an open-access article distributed under the terms of the Creative Commons Attribution License (CC BY 4.0), which permits unrestricted use, distribution, and reproduction in any medium, provided the original author and source are credited. 
Conventional wastewater treatment technologies are costly and energy demanding, which is problematic in rural areas with small communities (less than 2000 population equivalents). Constructed wetlands and sand filtration systems have been proposed as feasible alternatives with lower environmental impact compared to conventional technologies (e.g., activated sludge systems) after using LCA (Dixon et al., 2003; Palme et al., 2005; Machado et al., 2007; Foley et al., 2010; Musharaffie et al., 2011; Kalbar et al., 2012; Yildirim and Topkaya, 2012; Fitzsimons et al., 2014). Dixon et al. (2003) compared small horizontal flow reedbed system to package bio-filtrated plant, using energy use, $\mathrm{CO}_{2}$-emissions and soil emissions as impact categories. The energy use was quite similar for both of the alternatives and emissions of energy consumption of operation phase was the main source of the $\mathrm{CO}_{2}$ emissions. Transport included in operational function were a remarkable source for $\mathrm{CO}_{2}$ emissions of reedbed system.

Fitzimons et al. (2014) points out the significance of regional aspects when choosing right technological solution for small wastewater treatment plans. The use of energy is one of the most important sources of emissions. The number of environmental impacts caused by electricity can be avoided by using natural WWTPs (e.g., constructed wetlands), but they need much larger area in order to be installed (Fitzimons et al., 2014).

Applying LCA method two alternative wastewater treatment systems in rural areas were compared: energy-saving system (constructed wetland and slow rate infiltration) and a conventional one. The low environmental impact of the energy-saving wastewater treatment plants was demonstrated, most importantly, lower impact for global warming (Machado et al., 2007). Garfi et al. (2017) also compared a conventional wastewater treatment technology (activated sludge plant) to two nature-based technologies (hybrid constructed wetland and high-rate algal pond systems) using LCA. All these systems treated wastewater of 1500 population equivalent (PE) and the unit was $1 \mathrm{~m}^{3}$ of wastewater. It was found, that the nature-based systems were the more environmentally friendly compared to conventional WWTP due to the lower electricity and chemicals consumption (Garfi et al., 2017).

In summary, it is important to evaluate the advantages and disadvantages of various wastewater treatment technologies in order to find the most environmentally friendly ones that can be planned for installation in the future (Buyukkamaci, 2013).

The aim of the work was to determine the efficiency of wastewater treatment plants in rural areas and to assess their impact on the environment.

The work tasks were as follows:

- To calculate and compare the operation efficiency and dynamics of five wastewater treatment plants of small settlements in Ukmerge district according to the main pollution indicators: $\mathrm{BOD}_{7}$, total nitrogen (TN) and total phosphorus (TP) in the period 2017-2020.

- Carry out a Life Cycle Assessment of WWTPs using SimaPro 9.1.0.8 software according to the following indicators: sludge generated in the wastewater treatment process, fuel consumption for transport and electricity consumption.

\section{RESEARCH METHODS}

Five wastewater treatment plants in Ukmergè district, reconstructed during the same year (2013) were selected for the study: Dainava, Vidiškiai, Šventupè, Taujènai and Žemaitkiemis. The same vertical flow labyrinth technology (VFL) was applied to the reconstruction of all five wastewater treatment plants (Fig.1). It has been hypothesized that the efficiency and environmental impact of these WWTPS should be similar.

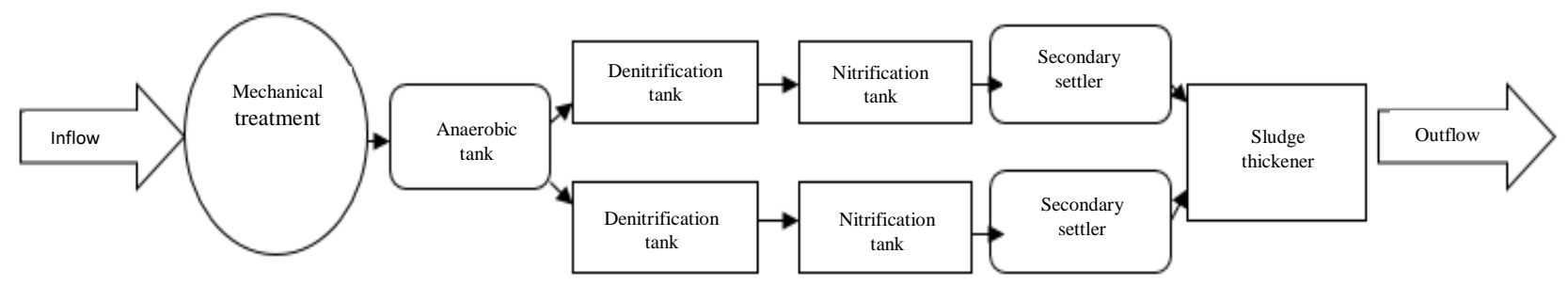

Figure 1. Vertical flow labyrinth (VFL) scheme

The process stages are aeration, sedimentation, biological nitrogen and phosphorus removal. Due to the biological removal of nitrogen and phosphorus in wastewater treatment plants, the AA / O technology scheme was applied. At low loads of activated sludge, an anoxic chamber is inserted between the anaerobic and aeration chambers. Wastewater flows into an anaerobic fermentation zone, mixes with activated sludge and flows into the denitrification zone. Then wastewater overflows into the aeration zone where proceed wastewater oxidation and nitrification processes and finally, the mixture of activated sludge flow into the sedimentation section.

Wastewater discharges, pollutant concentrations before and after treatment were analyzed, and WWTPs operating efficiencies for the period 2017-2020 were calculated and compared. The efficiency of wastewater treatment (\%) was calculated according to $\mathrm{BOD}_{7}, \mathrm{TN}$ and TP and the obtained results were compared with the values of the minimum treatment efficiency specified in the Wastewater Management Regulation (Wastewater Management ..., 2019).

Difference in wastewater treatment efficiency was evaluated using program STATISTICA, t-value was calculated. T-test was used, independent, by variables. Level of significance - differences were considered statistically (significant, if $\mathrm{p} \leq 0.05$ ). 
A linear trend was used and determination coefficient was calculated to evaluate the trend of change in wastewater treatment efficiency. This coefficient shows which changes in one attribute's (wastewater treatment effectiveness coefficients) values can be explained using change in another attribute's (time) values. Determination coefficient, in case of linear dependence, is equal to squared correlation coefficient between variables (attributes) $\mathrm{X}$ and $\mathrm{Y}$.

The LCA was performed using SimaPro 9.1.0.8 software to evaluate the environmental impact of the wastewater treatment plants. SimaPro is the world's most widely used life cycle assessment software, which corresponds to the following standards - ISO 14040: Principles and Framework and ISO 14044: Requirements and Guidelines (ISO 14040:2006; ISO 14044:2006). The LC-IA basic approach has been used for Life Cycle Assessment, which includes several categories of environmental impact. The environmental impact assessment of the five Ukmerge district wastewater treatment plants in 2020 was performed using the CML-IA baseline V3.06 / EU25 method.

\section{RESULTS}

The operational efficiency of WWTPs was evaluated according to $\mathrm{BOD}_{7}$, TN and TP for the period 2017-2020 (Fig.2). According to $\mathrm{BOD}_{7}$, the lowest efficiency of Taujènai wastewater treatment plant was determined (94-96\%). Statistically significant differences compared to all other WWTPs were found $-p \leq 0.05$. In all other plants wastewater treatment efficiency was similar, no statistically significant differences were found between them ( $\mathrm{p} \geq 0.05)$. The lowest TN treatment efficiency was determined in Dainava wastewater treatment plant (88-95\%). Statistically significant differences were found in these WWTPs: Dainava WWTP - Šventupe WWTP; Dainava WWTP - Vidiškiai; Dainava WWTP - Taujènai WWTP. In all other WWTPs TN treatment efficiency was similar, no statistically significant differences where found $(\mathrm{p} \geq 0.05)$. The lowest TP treatment efficiency was found in Žemaitkiemis wastewater treatment plant (72-85\%). Statistically significant differences were found: Žemaitkiemis WWTP - Vidiškiai WWTP; Žemaitkiemis WWTP - Dainava WWTP. Highest TP treatment efficiency was found in Šventupès WWTP (92-86\%). Statistically significant differences were found: Šventupe WWTP - Vidiškiai WWTP; Šventupe WWTP - Dainava WWTP; Šventupe WWTP - Taujènai WWTP; Šventupe WWTP - Žemaitkiemis WWTP. All other plants wastewater treatment operation efficiency was similar, no statistically significant differences were found $(\mathrm{p} \geq 0.05)$.
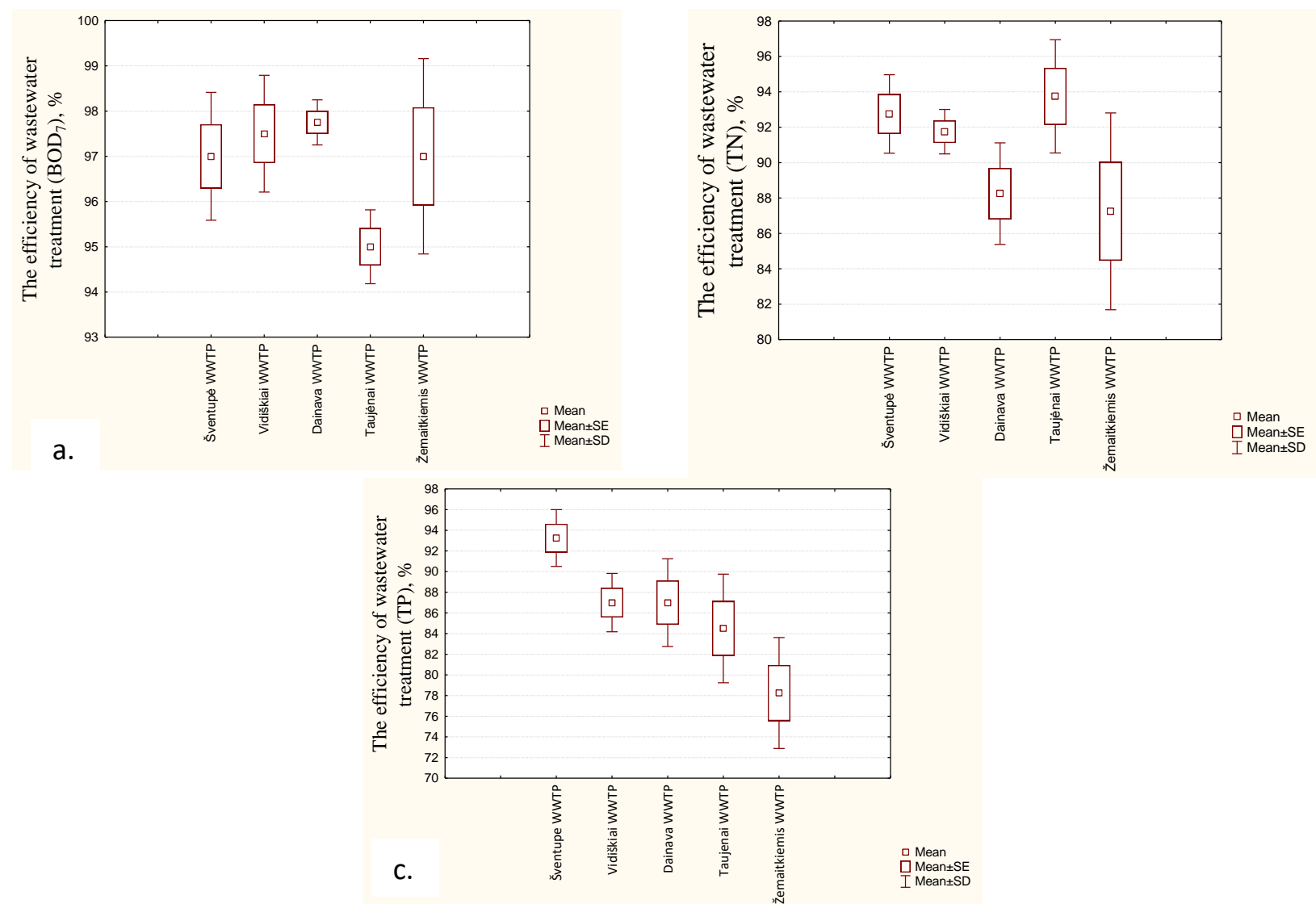

Figure 2. WWTPs operational efficiency according to $\mathrm{BOD}_{7}$ (a); according to $\mathrm{TN}$ (b); according to TP (c)

The dynamics of the operation efficiency of the studied wastewater treatment plants in the period of 2017-2020 according to the $\mathrm{BOD}_{7}, \mathrm{TN}$ and TP values is presented in Figure 3.

Trends of increase in $\mathrm{BOD}_{7}$ values were found in all WWTPs. It may be concluded that during the four-year period, according to $\mathrm{BOD}_{7}$, WWTP operation efficiency had been increasing.

Increasing trend of TN value coefficients were found in two WWTPs (Šventupe WWTP and Dainava WWTP); decreasing trend was found in three WWTPs (negative function: Vidiškiai, Taujènai and Žemaitkiemis WWTPs). 
Increasing trend of TP value coefficients were found in three WWTPs (positive function: Šventupè, Dainava and Taujènai WWTPs); decreasing trend of TP value coefficients was found in two WWTPs (negative function: Vidiškiai and Žemaitkiemis WWTPs).

The results show that the values of the operating efficiency of the studied wastewater treatment plants in the period of 2017-2020 corresponded to the values of the minimum treatment efficiency established by the Wastewater Management Regulation (2019) (except for Žemaitkiemis WWTP according to TP).

Three factors were analysed: sludge generated in the wastewater treatment process, fuel consumption for transporting sludge to the storage site and electricity consumption for wastewater and sludge treatment. It should be noted that the VFL method of wastewater treatment removes nitrogen and phosphorus biologically, so no chemicals were used that would have an impact on the environment and otherwise would also have to be assessed. The life cycle is assessed according to the 10 exposure categories.

In order to unify the results obtained by the program for all five wastewater treatment plants (discharges of treated wastewater are different in each treatment plant), the data were recalculated for $1 \mathrm{~m}^{3}$ of treated wastewater.

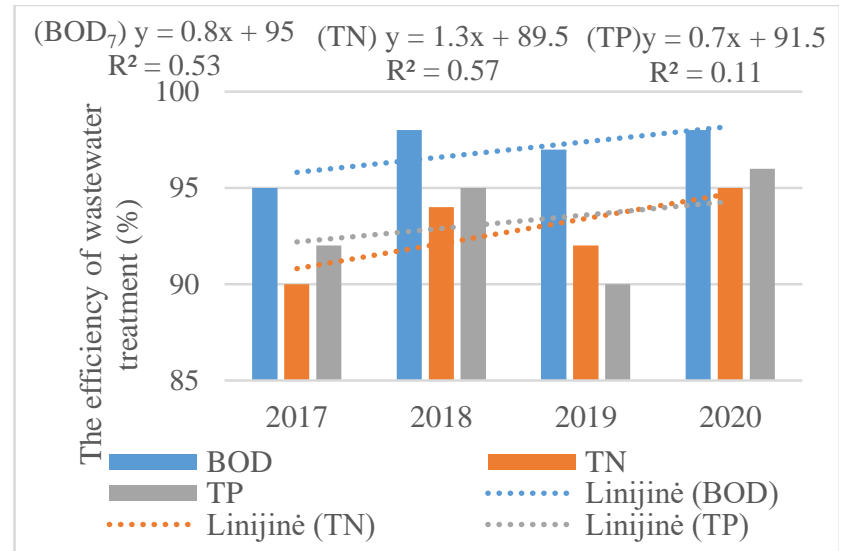

Šventupe WWTP

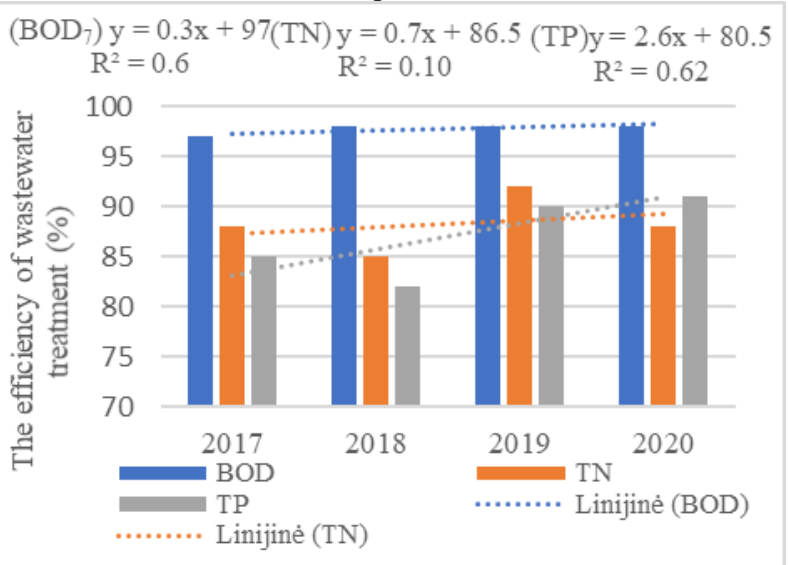

Dainava WWTP

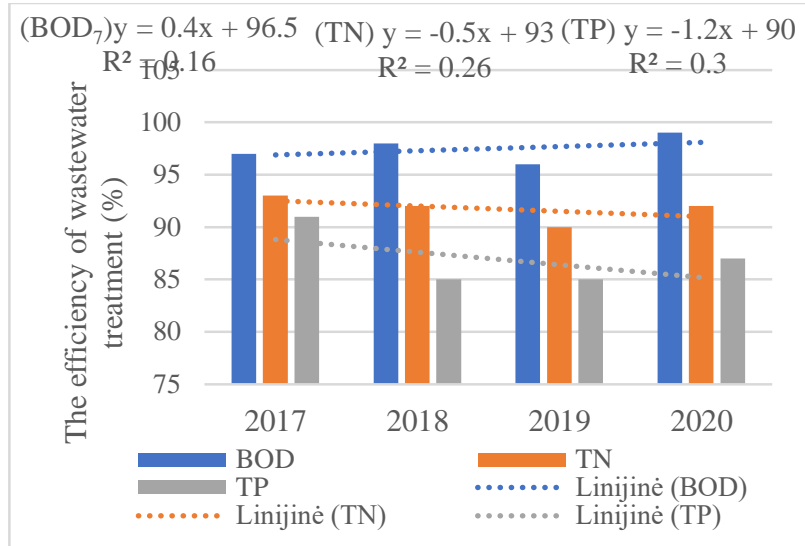

Vidiškiai WWTP

$\left(\mathrm{BOD}_{7}\right) \mathrm{y}=0.4 \mathrm{x}+94(\mathrm{TN}) \mathrm{y}=-2.1 \mathrm{x}+99 \quad(\mathrm{TP}) \mathrm{y}=2.2 \mathrm{x}+79$

$$
\mathrm{R}^{2}=0.4 \quad \mathrm{R}^{2}=0.72 \quad \mathrm{R}^{2}=0.29
$$

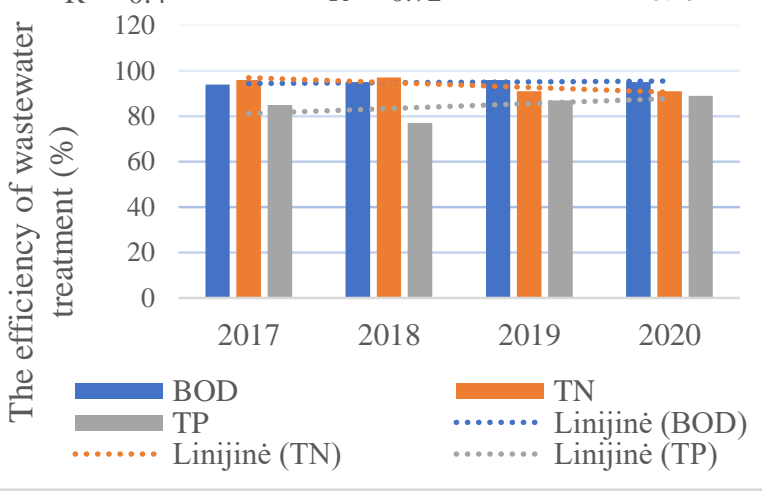

Taujënai WWTP

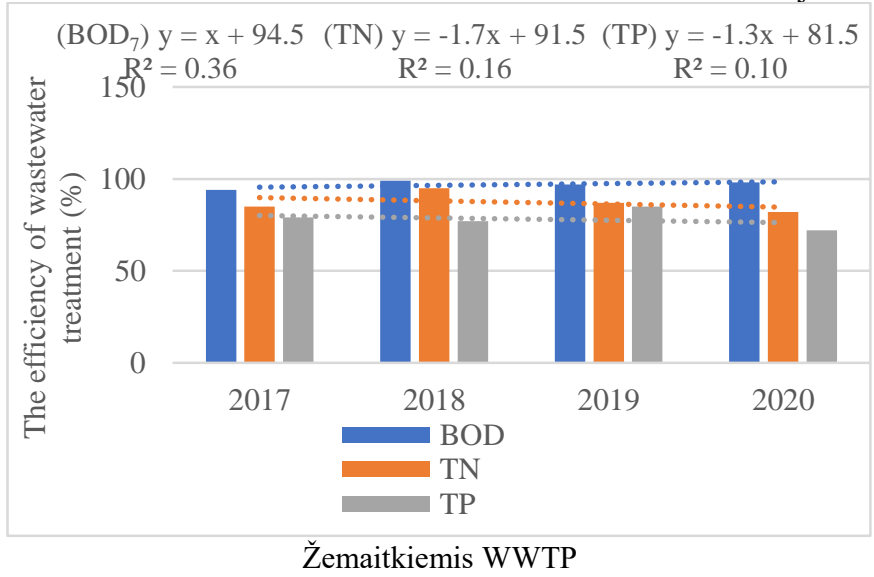

Figure3. Dynamics of operational efficiency of WWTPs in the period 2017-2020

A comparison of the total environmental impact of $1 \mathrm{~m}^{3}$ of treated wastewater from Ukmerge district WWTPs (consisting of sludge, fuel consumption for transport and electricity consumption) is presented in Table 1 . 
Table 1. Total environmental impact of $1 \mathrm{~m}^{3}$ of treated wastewater in five WWTPs of Ukmerge district

\begin{tabular}{|c|c|c|c|c|c|c|}
\hline \multirow{2}{*}{ Impact category } & \multirow{2}{*}{ Units } & \multicolumn{5}{|c|}{ Wastewater Treatment Plants } \\
\cline { 3 - 7 } & & Dainava & Taujënai & Vidiškiai & Šventupé & Žemaikiemis \\
\hline Abiotic depletion & $\mathrm{kg} \mathrm{Sb} \mathrm{eq}$ & 0.0001 & $5.69 \cdot 10^{-5}$ & 0.0001 & $5.6 \cdot 10^{-5}$ & $7.42 \cdot 10^{-5}$ \\
\hline Abiotic depletion (fossil fuels) & $\mathrm{MJ}$ & 106.921 & 60.506 & 151.635 & 59.380 & 78.881 \\
\hline Global warming potential & $\mathrm{kg} \mathrm{CO}$ eq & 7.723 & 4.370 & 10.953 & 4.293 & 5.680 \\
\hline Ozone layer depletion & $\mathrm{kg} \mathrm{CFC}-11 \mathrm{eq}$ & $2.66 \cdot 10^{-5}$ & $1.45 \cdot 10^{-5}$ & $3.74 \cdot 10^{-5}$ & $1.45 \cdot 10^{-5}$ & $1,94 \cdot 10^{-5}$ \\
\hline Human toxicity & $\mathrm{kg} \mathrm{1,4-DB} \mathrm{eq}$ & 8.141 & 4.553 & 11.477 & 4.471 & 5.938 \\
\hline Fresh water aquatic ecotoxicity & $\mathrm{kg} \mathrm{1,4-DB} \mathrm{eq}$ & 5.042 & 2.822 & 7.112 & 2.796 & 3.606 \\
\hline Terrestrial ecotoxicity & $\mathrm{kg} \mathrm{1,4-DB} \mathrm{eq}$ & 0.043 & 0.024 & 0.061 & 0.024 & 0.030 \\
\hline Photochemical oxidation & $\mathrm{kg} \mathrm{C}_{2} \mathrm{H}_{4} \mathrm{eq}$ & 0.002 & 0.001 & 0.002 & 0.001 & 0.001 \\
\hline Acidification & $\mathrm{kg} \mathrm{SO}_{2} \mathrm{eq}$ & 0,046 & 0.026 & 0,065 & 0.025 & 0.034 \\
\hline Eutrophication & $\mathrm{kg} \mathrm{PO}_{4} \mathrm{eq}$ & 0.026 & 0.014 & 0.036 & 0.014 & 0.018 \\
\hline
\end{tabular}

Figure 4 presents the Life Cycle Assessment in presents of one of the analysed wastewater treatment plants Vidiškiai WWTP according to three factors. As can be seen from the graph, the largest negative impact in all categories is sewage sludge, followed by electricity consumption, the lowest - fuel consumption for transport.

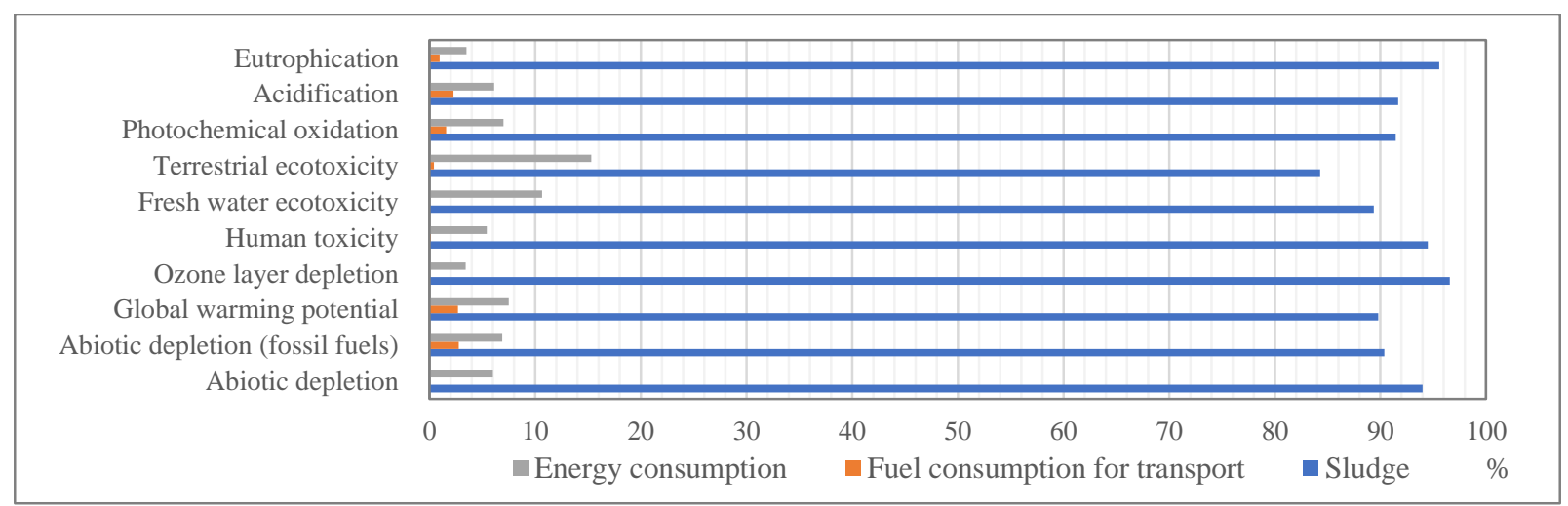

Figure 4. Life Cycle Assessment (LCA) of Vidiškiai WWTP, 2020

The greatest effect of sludge was found on ozone layer depletion. In Žemaitkiemis WWTP it reached $98 \%$, in Dainava and Vidiškiai WWTPs it accounted for 97\%, in Taujènai and Šventupè WWTPs - 96\%.

The electricity consumed in the wastewater treatment process had the greatest impact on global warming potential in Dainava WWTP - 7\%. In the other four wastewater treatment plants, the greatest impact of electricity was in the category of ecotoxicity to terrestrial ecosystems, respectively: Žemaitkiemis WWTPs accounted for 10\%, Vidiškiai and Taujènai WWTPs - 15.5\%, Šventupè WWTP - 17.6\%.

Fuel consumption for transport had the greatest impact on abiotic depletion potential (fossil fuels), respectively Žemaitkiemis WWTP - 4\%, Taujènai WWTP - 3.3\%, Šventupe WWTP - 3\%, Vidiškiai WWTP - 2.8\% and Dainava WWTP $-2.1 \%$.

Figure 5 presents a comparison of the environmental impact of wastewater treatment plants according to the very important categories of acidification and eutrophication for surface water bodies.

It was found that the Vidiškiai wastewater treatment plant has the greatest negative impact on the environment in all 10 categories studied, including acidification $\left(0.066 \mathrm{~kg} \mathrm{SO}_{2} \mathrm{eq}\right)$ and eutrophication $\left(0.036 \mathrm{~kg} \mathrm{PO}_{4}\right.$ eq). The smallest amount of wastewater was treated in Vidiškiai WWTP $\left(6090 \mathrm{~m}^{3}\right.$ in 2020 , i.e., 2-4 times less than in the other four WWTPs) and a significantly higher amount of sludge per $1 \mathrm{~m}^{3}$ of treated wastewater was generated. In addition, Vidiškiai WWTP consumes the most electricity $\left(2.1 \mathrm{kWh} / \mathrm{m}^{3}\right.$, i.e., $1.5-3$ times more than in other WWTPs studied).

It was observed that the smaller the size of the activated sludge wastewater treatment plants, the higher the electricity.

consumption per $1 \mathrm{~m}^{3}$ of treated water (Lorenzo-Toja et al., 2015). In the study of Life Cycle Assessment of wastewater treatment systems for small communities (Garfi et al., 2017), the high electricity consumption was the main responsible for the low environmental performance of such type of wastewater treatment plants.

The negative impact of Šventupe WWTP on the environment is the smallest (e.g., according to acidification $0.026 \mathrm{~kg} \mathrm{SO}_{2}$ eq, according to eutrophication $-0.014 \mathrm{~kg} \mathrm{PO}_{4}$ eq), i.e., 2.6 times smaller than Vidiškiai WWTP.

Summarizing the impact of Ukmerge district wastewater treatment plants on the environment, it can be stated that the results do not differ significantly due to the similar landscape of the territory, wastewater treatment and sludge treatment technologies, and other indicators. However, transport flows in the analysed WWTPs differ slightly (different distances from WWTPs to sludge storage site) and affect the environment in terms of ecotoxicity, eutrophication, acidification, global warming potential, and other categories.

As the vertical flow labyrinth technology, which was applied to the reconstruction of the treated wastewater treatment plants, uses little electricity, this indicator does not have a significant impact on the environment. Also, facility occupies small area, and removal of nutrients (TN and TP) does not require the use of chemicals. 


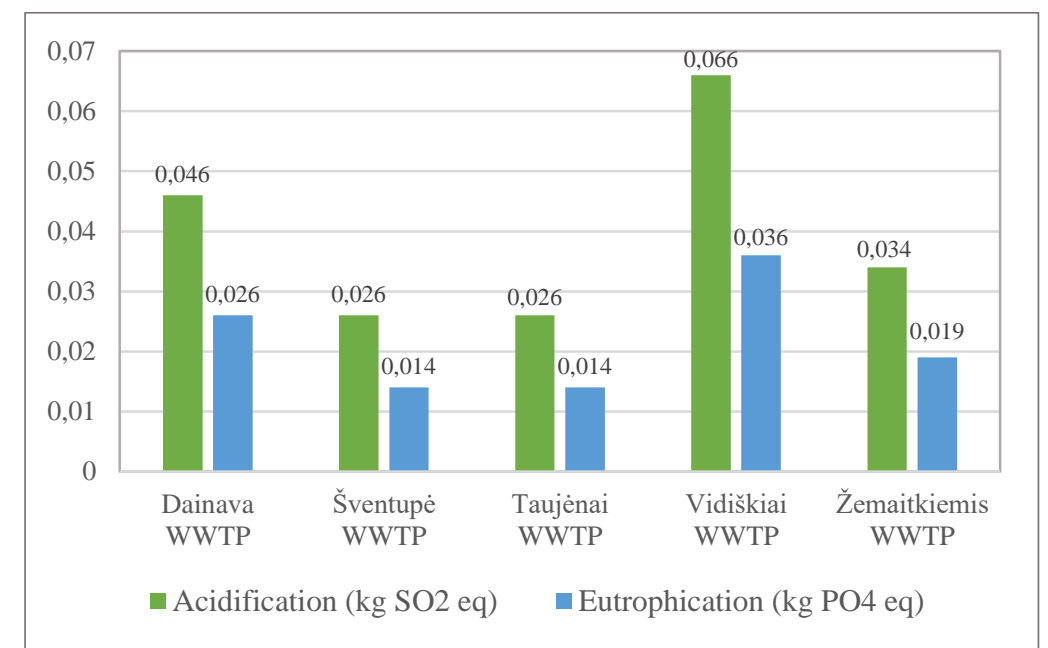

Figure 5. LCA of WWTPs by acidification and eutrophication

In 2016-2019 during the implementation of the Interreg BSR project "VillageWaters (Water emissions and their reduction in village communities in Baltic Sea Region as pilots)", the environmental impacts were calculated of the pilots of the project - small WWTPs in rural areas of five countries (Finland, Estonia, Latvia, Lithuania and Poland). The LCA calculations were done to the old and to the new wastewater treatment technologies. Lithuanian pilot - Leitgiriai village (Šilute district) wastewater treatment plant was reconstructed using vertical flow labyrinth technology. The LCA results showed a significant reduction in environmental effects in various categories, such as the eutrophication impact reduced because of the changes 64\% (Sylvenius et al., 2019).

Based on the analysis, it can be stated that the VFL wastewater treatment technology is suitable for application in rural areas not only in terms of operational efficiency, but also in terms of environmental protection. Overall result is that environmental impact can be reduced very much by implementing technology which is suited for the circumstances.

\section{CONCLUSIONS}

1. Based on the analysis of the five small wastewater treatment plants in Ukmerge district, reconstructed by applying the same vertical flow labyrinth (VFL) technology in the four-year period (2017-2020), it can be stated that according to $\mathrm{BOD}_{7}$, the operating efficiency of all wastewater treatment plants increased. According to total nitrogen, the treatment efficiency of two wastewater treatment plants increased - Šventupè and Dainava WWTPs, according to total phosphorus - Šventupè, Dainava and Taujènai WWTPs.

2. The vertical flow labyrinth wastewater treatment technology is suitable for application in rural areas not only in terms of operational efficiency, but also in terms of environmental protection. Of the three factors: sludge generated in the wastewater treatment process, fuel consumption for transport and electricity consumption for wastewater treatment examined, sludge has been found to have the highest environmental impact and fuel consumption for transport - the lowest.

\section{REFERENCES}

1. Acero A. P., Rodríguez C., Ciroth A. 2017. LCIA methods impact assessment methods in Life Cycle Assessment and their impact categories. Greendeta, Berlin.

2. Buyukkamaci N. 2013. Life Cycle Assessment Applications in Wastewater Treatment. Journal of Pollution Effects \& Control, Vol. 1 (2), pp.1-2.

3. Dixon A., Simon M., Burkitt T. 2003. Assessing the environmental impact of two options for small-scale wastewater treatment: comparing a reedbed and an aerated biological filter using a life cycle approach. Ecological engineering, Vol. 20, pp. $297-308$. https://doi.org/10.1016/S0925-8574(03)00007-7

4. Environmental Assessment of Products, Vol. 1: Methodology, tools and case studies in product development. 2000. Eds.: Wenzel H., Hauschild M., Alting L. Kluwer Academic Publishers, Boston.

5. Fitzaimons L., McNamara G., Dohery E., Clifford E. 2014. Optimal Design and Operation of Small-scale Wastewater Treatment Plants: The Irish Case. EPA Research Report. Environmental Protection Agency, Dublin City University.

6. Foley J., de Haas D., Harley K., Lant P. 2010. Comprenensive life-cycle inventories of alternative wastewater treatment systems. Water Research, Vol. 44, pp. 1654-1666. https://doi.org/10.1016/j.watres.2009.11.031

7. Garfi M., Flores L., Ferrer I. 2017. Life Cycle Assessment of wastewater treatment systems for small communities: Activated sludge, constructed wetlands and high rate algal ponds. Journal of Cleanest Production, Vol. 161, pp. 211-219. https://doi.org/10.1016/j.jclepro.2017.05.116

8. Goedkoop M., De Schryver A., Oele M., Durksz S., de Roest D. 2010. Introduction to LCA with SimaPro 7PRé Consultants, Amersfoort, The Netherlands. 
9. ISO 14044:2006. Environmental Management - Life Cycle Assessment - Requirements and Guidelines. 2006. International Standards Organisation, Geneva. Available at https://www.iso.org/standard/37456.html

10. ISO 14040:2006. Environmental Management - Life Cycle Assessment - Principles and Framework. 2006. International Standards Organisation, Geneva. Available at https://www.iso.org/standard/37456.html

11. Kalbar P. P., Karmakar S., Asolekar S. R. 2012. Technology assessment for wastewater treatment using multiple-attribute decision-making. Technology in Society, Vol. 34 (4), pp. 295-302. https://doi.org/10.1016/j.techsoc.2012.10.001

12. Lorenzo-Toja Y., Vazquez-Rowe I., Chenel S., Marín-Navarro D., Moreira M.T., Feijoo G., 2015. Eco-efficiency analysis of Spanish WWTPs using the LCA p DEA method. Water Resources, Vol. 68, p.p. $651-666$. https://doi.org/10.1016/j.watres.2014.10.040

13. Machado A. P., L. Urbano, L., Brito, A. G., Janknecht, P., Salas, J. J., Nogueira, R. 2007. Life cycle assessment of wastewater treatment options for small and decentralized communities. Water Science and Technology, Vol. 56 (3), pp. 15-22. https://doi.org/10.2166/wst.2007.497

14. Muñoz I., Milà-i-Canals L., Fernández-Alba A. R. 2010. Life Cycle Assessment of Water Supply Plans in Mediterranean Spain. Journal of Industrial Ecology, Vol. 14 (6), pp. 902-918. https://doi.org/10.1111/j.1530-9290.2010.00271.x

15. Musharrafie A., Güereca P. L., Padilla A., Morgan J. M., Noyola A. 2011. A Comparison of Two Wastewater Treatment Plants: Stabilization ponds and Activated Sludge with a Social perspective impacts, MX. IDRC-Related Report. Instituto de Ingeniería, Universidad Nacional Autónoma de México, México.

16. Navickas K., Venslauskas K. 2012. Biomass Life Cycle Analysis (Biomasès būvio ciklo analizè). LŽŪU Leidybos centras, Akademija.

17. Palme U., Lundin M., Tillman A.M., Molander S. 2005. Sustainable development indicators for wastewater systems - researchers and indicator users in a co-operative case study. Resources Conservation and Recycling, Vol. 43, pp. $293-311$. https://doi.org/10.1016/j.resconrec.2004.06.006

18. Rebitzer G., Hunkeler D., Jolliep O. 2003. LCC-The Economic Pillar of Sustainability: Methodology and Application to Watewater Treatment. Environmental Progress, Vol. 22(4), pp. 241-249. https://doi.org/10.1002/ep.670220412

19. Silvenius F., Vorne V., Virtanen Y. 2019. Life Cycle Assessment for VillageWaters Pilot Villages VillageWaters. Internal report - Version 2.0. Available at https://villagewaters.eu/Project_reports_994 9 (accessed on 2403 2021).

20. Sperling M. 2007. Biological Wastewater Treatment Series. Vol.1. Wastewater Characteristics, Treatment and Disposal. IWA Publishing, London, UK. Available at: https://sswm.info/sites/default/files/reference_attachments/VON\%20SPERLING\%202007.\%20Wastewater\%20Characteristics $\% 2 \mathrm{C} \% 20$ Treatment\%20and\%20Disposal.pdf (accessed on 3008 2021).

21. Tillman A. M., Baumann H., 2004. The Hitch Hiker's Guide to LCA. 1:7 Edition. Studentlitteratur, Lund, Sweden.

22. Zimele Z., Sinka M., Korjakin A., Bajare D., Sahmenko G. 2019. Life Cycle Assessment of Foam Concrete Production in Latvia. Environmental and Climate Technologies, Vol. 23 (3), pp. 70-84. https://doi.org/10.2478/rtuect-2019-0080

23. Wastewater Management Regulation (Nuoteku tvarkymo reglamentas) 2019. Order of the Minister of the Environment of the Republic of Lithuania: 17 May 2006. No. D1-236. Recast from 2019. Available at https://eseimas.lrs.lt/portal/legalAct/lt/TAD/TAIS.276576/bJLwtUrcMj (accessed on 1501 2021).

24. Yildirim M., Topkaya,B. 2012. Assessing Environmental Impacts of Wastewater Treatment Alternatives for Small-Scale Communities. CLEAN - Soil, Air, Water, Vol. 40 (2), pp. 171-178. https://doi.org/10.1002/clen.201000423

25. Zhang, L. X., Wang, C. B., Song, B. 2013. Carbon emission reduction potential of a typical household biogas system in rural China. Journal of Cleaner Production, Vol. 47, pp. 415-421. https://doi.org/10.1016/j.jclepro.2012.06.021 